\title{
Dampak Kebijakan Rencana Tata Ruang Wilayah Terhadap Iklim Investasi Bidang Usaha Perkebunan di Provinsi Riau
}

\author{
Hasnati, Yalid*, Rezmia Febrina \\ Fakultas Hukum Lancang Kuning \\ Jalan Yos Sudarso Km 8, Rumbai, Kota Pekanbaru, Indonesia
}

\begin{abstract}
Abstrak
Tujuan penelitian ini untuk menjelaskan dampak kebijakan RTRW terhadap iklim investasi bidang usaha perkebunan di Provinsi Riau. Penelitian ini menggunakan metode penelitian hukum sosiologis dengan pendekatan empiris. Hasil penelitian ini dapat dijelaskan bahwa fenomena fundamental yang mempengaruhi iklim investasi di Provinsi Riau. Belum selesainya RTRW berdampak besar terhadap investasi karena setiap investasi membutuhkan lahan/lahan. Sampai saat ini, Perda RTRW Provinsi Riau belum terbentuk, karena masih ada status resolusi masalah hutan di Kementerian Kehutanan. Penelitian ini menyimpulkan bahwa Pemerintah Provinsi Riau pada tahun 2001 sudah memulai melakukan revisi terhadap Perda Nomor 10 Tahun 1994 tersebut. Tetapi, sampai dilakukannya penelitian ini Perda RTRW Provinsi Riau belum ditetapkan, karena memang masih ada penyelesaian masalah status kawasan hutan di Kementerian Kehutanan. Tentunya, Pemerintah Daerah Provinsi Riau termasuk daerah kabupaten/kota di Riau tidak berani mengambil risiko hukum menerbitkan izin baru untuk investasi perkebunan. Upaya yang dilakukan di tengah ketidakpastian kebijakan RTRW terhadap investasi bidang usaha perkebunan di Provinsi Riau dapat dikatakan hanya menunggu pengesahan Perda RTRW Provinsi Riau.
\end{abstract}

\section{Kata Kunci: RTRW, Investasi, Perkebunan}

\begin{abstract}
The purpose of this study is to explain the impact of RTRW policy on investment climate in the field of plantation business in Riau Province. This research uses sociological law research method with empirical approach. The result of this research can be explained that fundamental phenomenon influencing investment climate in Riau Province. The unfinished RTRW has a major impact on investment because every investment requires land. Until now, Riau Province RTRW regulation has not been established yet, because there is still the status of forest problem resolution in the Ministry of Forestry. This research concludes that the Government of Riau Province in 2001 has started to revise the Regulation No. 10 of 1994. However, until this research, Riau Province RTRW regulation has not been established yet, because there is still a solution to the status of forest area in the Ministry of Forestry. Of course, the Riau Provincial Government, including the districts / municipalities in Riau, dare not take legal risks issuing new licenses for plantation investment. Efforts made in the middle of the policy discretion RTRW investment in the field of plantation business in Riau Province can be said just waiting for ratification of RTRW Perda Riau Province.
\end{abstract}

Keywords: RTRW, Investment, Plantation

\footnotetext{
*Penulis Korespondensi

E-mail: yalid@unilak.ac.id
} 


\section{Pendahuluan}

Kewajiban negara dalam mendorong optimalisasi kegiatan investasi merupakan konsekuensi logis dari negara Indonesia yang bercorak negara hukum kesejahteraan. Negara hukum kesejahteraan pada dasarnya lazim disebut dengan negara hukum materil atau negara kesejahteraan (welfare state) merupakan negara dengan seperangkat pemerintahannya tidak saja bertanggung jawab terhadap pemeliharaan ketertiban dan ketentraman rakyatnya, tetapi juga bertanggung jawab terhadap kesejahteraan ekonomi rakyatnya. ${ }^{1}$

Indonesia sampai saat ini menempatkan investasi sebagai sumber pembiayaan pembangunan dan mendorong pertumbuhan ekonomi yang tidak mampu dikelola negara karena alasan keterbasan, seperti tidak mempunyai dana, sumber daya manusia, teknologi dan lain sebagainya.

Menurut Mahmul Siregar "dari pada berutang maka peran investasi sebagai alternatif terbaik sumber pembiayaan pembangunan. Selain itu, investasi sebagai alat untuk mengintegrasikan ekonomi suatu negara ke dalam ekonomi global". ${ }^{2}$ Investasi dapat menghasilkan multiplayer effect terhadap pembangunan ekonomi nasional, karena kegiatan investasi tidak saja mentransfer modal dan barang, tetapi juga mentransfer ilmu pengetahuan dan sumber daya manusia, ${ }^{3}$ memperluas lapangan kerja, mengembangkan industri substitusi impor untuk menghemat devisa, mendorong ekspor non migas untuk menghasilkan devisa, alih teknologi, membangun prasarana, dan mengembangkan daerah tertinggal. ${ }^{4}$ Oleh karena itu, banyak negara tidak terkecuali Indonesia menjadikan kegiatan investasi sebagai bagian dari penyelenggaraan perekonomian nasionalnya.

Untuk mengundang minat investor berinvestasi, bukanlah hal yang mudah. Perlu dilakukan upaya serius, sistematik, terintegrasi dan konsisten untuk menanamkan kepercayaan pada investor agar berinvestasi di wilayah host country. Harus diingat bahwa pertimbangan investor sebelum menanamkan modal selalu dilandasi motivasi ekonomi untuk menghasilkan keuntungan dari modal dan seluruh sumber daya yang dipergunakannya. Oleh karena itu, investor selalu melakukan kajian awal (feasibility study) terhadap aspek ekonomi, politik dan aspek hukum sebelum mengambil keputusan untuk berinvestasi. Terkait hal ini, setidak-tidaknya calon investor akan mempertimbangkan aspek economic opportunity, political stability dan legal certainty. ${ }^{5}$ Ketiga aspek inilah yang menjadi syarat mutlak pada host country agar menarik bagi calon investor.

Pertimbangan utama suatu negara mengoptimalkan peran investasi baik dalam

${ }^{1}$ Duhita Driyah Suprapti, Politik Hukum Investasi di Era Otonomi Daerah, Jurnal Pandecta, Volume 4 , Nomor 2, Tahun 2010, hlm. 7.

${ }^{2}$ Dellisa A. Ridgway dan Mariya A. Thalib, Globalization and Development : Free Trade, Foreign Aid, Investment and The Rule of Law, California Western International Law Journal, Volume 33, Spring 2003, hlm. 335.

${ }^{3}$ Hans-Rimbert Hemmer, et.all., Negara Berkembang dalam Proses Globalisasi Untung atau Buntung? (Jakarta: Konrad Adenauer Stifftung, 2002), hlm. 11.

${ }^{4}$ Erman Rajagukguk, Hukum Investasi di Indonesia, (Jakarta: Fakultas Hukum Universitas Indonesia, 2005), hlm. 19.

${ }^{5}$ Pancras J. Nagy dalam Mahmul Siregar, Kepastian Hukum dalam Transaksi Bisnis Internasional dan Implikasinya Terhadap Kegiatan Investasi di Indonesia, (Medan: Program Studi IImu Sekolah Pascasarjana Universitas Sumatera Utara, 2010), hlm. 2. 
negeri maupun asing adalah untuk merubah potensi ekonomi menjadi kekuatan ekonomi riil dalam rangka meningkatkan pertumbuhan ekonomi (economic growth). Cukup banyak analisis dan publikasi tentang kondisi iklim investasi di Indonesia yang khawatir tentang kondusifitas berinvestasi di Indonesia. Djisman S. Simanjuntak, menyoroti gangguan keamanan, amuk penjarahan, ketidakpastian hukum, korupsi dan perselisihan perburuhan telah memudarkan daya tarik Indonesia ketika di negara lain muncul lokasi cerah untuk berinvestasi. $^{6}$

Todung Mulya Lubis mengemukakan selain kurang memadainya infrastruktur investasi maka hambatan utama berupa kepastian hukum. Menurutnya pengadilan di Indonesia khususnya Pengadilan Negeri dan Pengadilan Tinggi sering dengan sengaja atau tidak mengabaikan isi perjanjian yang berlaku di antara pihak terkait, termasuk dalam sejumlah transaksi sudah dilaksanakan. Sikap lembaga peradilan yang kurang menghargai keabsahan kontrak kerja sama itu, memberi sinyal negatif atas komitmen Indonesia dalam melaksanakan reformasi hukum dan penegakan keadilan. Sejumlah kasus, termasuk Manulife, Prudential, PT Danareksa Jakarta, PT Tripolyta, dan Asia Pulp \& Paper serta anak perusahaannya di Indonesia menggambarkan ketidakpedulian lembaga pengadilan terhadap legitimasi transaksi komersial yang dibuat berdasar perjanjian internasional. Kondisi ini menimbulkan dampak besar terhadap tingkat risiko Indonesia di pasar modal internasional dan atas arus modal langsung. ${ }^{7}$
Terkait masalah kepastian hukum Mc. Cawley juga menggambarkan kepastian hukum investasi di Indonesia. Dalam tulisannya ia mengemukakan "tiap regulasi, sepertinya menimbulkan regulasi uraian yang lain, sehingga pada akhirnya para pejabat rendah di kantor-kantor daerah dan pelabuhan merasa bebas bahkan harus menetapkan hal yang samar-samar dengan mengeluarkan regulasinya sendiri. Situasi yang biasanya tidak memuaskan ini seringkali dicampuri dengan tendensi pejabat senior untuk menerobos semua pita merah dan kelambatan dengan memberikan pembebasan dari peraturan atau dengan membuat keputusan umum sebagai undang-undang "yang dikehendaki". Ketika ini terjadi, seringkali tidak jelas apakah mereka mengungkapkan pernyataan mereka sendiri atau benar-benar menerapkan peraturan pemerintah". ${ }^{8}$

Pemerintah Indonesia memahami kelemahan dari iklim investasi tersebut dan telah melakukan upaya-upaya ke arah perbaikan. Upaya yang cukup fundamental, yakni dengan mengeluarkan Undang-Undang Nomor 25 Tahun 2007 tentang Penanaman Modal, menggantikan Undang-Undang Nomor 1 Tahun 1967 tentang Penanaman Modal Asing dan Undang-Undang Nomor 6 Tahun 1968 tentang Penanaman Modal Dalam Negeri karena dipandang tidak sesuai kebutuhan percepatan perkembangan perekonomian dan pembangunan hukum nasional khususnya di bidang penanaman modal. Pasal 3 Undang-Undang Nomor 25 Tahun 2007 mencantumkan asas kepastian hukum pada urutan pertama dari 10

${ }^{6}$ Djisman S. Simanjuntak, Ekonomi Pasar Sosial Terbuka Indonesia : Landasan Stabilitas dalam Ekonomi Global yang Berubah Dramatik, Makalah dalam Seminar Nasional yang diselenggarakan oleh Ikatan Alumni dan Fakultas Ekonomi Unpar, Bandung, 2004, hlm. 2.

${ }^{7}$ Todung Mulya Lubis dalam dalam Mahmul Siregar, Kepastian Hukum...Loc. Cit.

${ }^{8}$ Mc. Cawley dalam Mahmul Siregar, Kepastian Hukum...Op.Cit., hlm. 3. 
asas penyelenggaraan penanaman modal di Indonesia.

Hadirnya Undang-Undang Nomor 25 Tahun 2007 tentang Penanaman Modal merupakan langkah maju dan signifikan dari aspek hukum untuk menarik minat investor. Meskipun demikian kehadiran Undang-Undang Nomor 25 Tahun 2007 tersebut tidak serta menjadikan seluruh permasalahan hukum bidang penanaman modal di Indonesia menjadi terselesaikan. Kegiatan penanaman modal bersifat kompleks, karena tidak hanya terkait satu undang-undang saja. Hukum penanaman modal tidak hanya terkait dengan UndangUndang Nomor 25 Tahun 2007 dan peraturan pelaksananya, tetapi akan terkait dengan bidang hukum lain, seperti hukum perpajakan, hukum ketenagakerjaan, hukum pertanahan, hukum tata ruang wilayah, hukum perdagangan dan bidang hukum lain terkait transaksi bisnis baik berdimensi nasional maupun internasional.

Kepastian hukum dalam penanaman modal harus meliputi seluruh substansi hukum yang terkoneksi dengan penanaman modal termasuk struktur dan kultur hukumnya. Dengan demikian, kepastian hukum tidak saja meliputi kepastian substansi hukum, tetapi juga penerapannya dalam struktur hukum, seperti putusan badan peradilan dan kultur dimasyarakatnya.

Untuk menciptakan substansi hukum yang berkaitan dengan penanaman modal dalam skala daerah, seperti peraturan daerah (perda) diharapkan sinkron dan harmonis dengan hukum nasional. Selain itu, hukum investasi skala daerah seharusnya diarahkan untuk mengkondisikan perbaikan ekonomi rakyat di daerah melalui kebijakan-kebijakan yang mendukung kegiatan investasi.

Dalam skala daerah, seperti Provinsi Riau layak menjadi fokus kajian penelitian, karena daerah ini dipandang luar biasa dalam memantapkan iklim investasi, bahkan Riau pada tahun Februari 2012 yang lalu menerima penghargaan Regional Champions dari Badan Koordinasi Penanaman Modal (BKPM). Penghargaan tersebut diberikan karena Provinsi Riau dinilai dan termasuk salah satu provinsi paling siap untuk investasi. Dari 33 provinsi, BKPM memilih 7 provinsi yang dianggap paling siap untuk investasi, selain Riau, ada Sumsel, Jawa Barat, Jawa Timur, Kalimantan Timur, NTB dan Papua.

Provinsi Riau dianggap paling siap menerima investasi, mengingat potensi yang luar biasa di daerah ini, selain urusan birokrasi terkait investasi yang tidak lagi rumit juga industri hulu sudah luar biasa. Hanya saja tinggal bagaimana mengembangkan industri hilirnya, sehingga bisa memberikan value added. ${ }^{9}$

Kesiapan Riau dalam investasi tidak hanya cukup mengandalkan potensi yang luar biasa dan birokrasi yang tidak lagi rumit saja, tetapi dari segi hukum investasi tidak ada yang bermasalah dari aspek sinkronisasi atau harmonisasinya yang berdampak pada ketidakpastian hukum. Fenomena mendasar yang berpengaruh terhadap kepastian hukum investasi di Provinsi Riau karena belum selesainya rencana tata ruang wilayah (RTRW). Belum selesainya RTRW tersebut besar sekali pengaruhnya, karena hampir semua bidang usaha akan terkena imbasnya.

${ }^{9}$ nilai tambah kepada ekonomi masyarakat, (http://www.pekanbaruexpress.com/metropolis/81-provinsi/ 1010-gubri-terima-qregional-championsq-dari-bkpm, terakhir kali diakses 11 September 2016. 
Tidak dapat dipungkiri setiap investasi membutuh lahan/tanah untuk kegiatan usahanya. Apalagi investasi perkebunan di Riau dalam penyusunan tata ruang kerap tumpang tindih dengan penguasaan lahan yang dikelola masyarakat dan perusahaan. Hal ini berpengaruh terhadap lambatnya proses mengurus izin dan pengukuran ulang lahan perusahaan dengan sendiri mengakibatkan pelambatan pengembangan sektor perkebunan.

Penyelesaian RTRW juga dapat menyelesaikan konflik lahan yang kerap terjadi antara perusahaan dengan masyarakat setempat di Riau. Tidak hanya untuk sektor perkebunan, penyelesaian RTRW juga diyakini dapat mempercepat pengembangan infrastruktur di Riau. Selama ini, pembangunan Provinsi Riau terkesan stagnan, karena kekhawatiran pemangku kepentingan melanggar tata ruang.

Hamsani Rahman selaku Kepala Bidang Fasilitasi dan Kerjasama pada Badan Koordinasi Penanaman Modal dan Promosi Daerah (BKPMPD) Provinsi Riau mengemukakan banyak perusahaan dari berbagai negara membatalkan investasinya di Riau. Kepastian hukum harus dibayar mahal dengan hilangnya investasi yang jumlahnya puluhan triliun. Menurut Hamsani, kejadian terbaru batalnya investasi perusahaan $\mathrm{KAO}$ asal jepang yang akan menanamkan modalnya di Dumai. Selain itu, ada juga perusahaan maritim Korea yang berencana membangun investasi di Buruk
Bakul Bengkalis. Semuanya batal, padahal kalau dihitung jumlahnya mencapai puluhan triliun. ${ }^{10}$

Sebagaimana telah disingggung kegiatan penanaman modal bersifat sangat kompleks, karena akan terkait dengan bidang hukum lain seperti perpajakan, ketenagakerjaan, pertanahan, tata ruang wilayah, perdagangan, dan hukum transaksi bisnis baik berdimensi nasional maupun internasional. Bila diteliti secara keseluruhan tentu terlalu luas. Meskipun kompleks, Penulis perlu memetakan secara bertahap untuk melakukan inventarisasi dan analisis peraturan dalam bidang investasi di Provinsi Riau yang hasilnya diharapkan dapat menjelaskan konsistensinya. Sejalan dengan maksud tersebut dalam penelitian ini penulis fokus meneliti tentang dampak kebijakan RTRW terhadap iklim investasi bidang usaha perkebunan di Provinsi Riau".

Penelitian tentang dampak kebijakan tersebut belum pernah disentuh sebelumnya oleh penulis lain. Beberapa terdahulu diantaranya Annisha meneliti tentang dampak kebijakan pelayanan perizinan terpadu dan penanaman modal terhadap daya tarik investasi asing di Provinsi Riau tahun 2013-2016. ${ }^{11}$ Eko $\mathrm{N}$ Setiawan dkk, meneliti tentang konflik tata ruang kehutanan dengan tata ruang wilayah (studi kasus penggunaan kawasan hutan tidak prosedural untuk perkebunan sawit Provinsi Kalimantan Tengah). ${ }^{12}$ Sudirman dkk, meneliti tentang mekanisme penyusunan kebijakan daerah di bidang kehutanan proses, imple-

\footnotetext{
${ }^{10} \mathrm{http}: / /$ riausky.com/news/detail/6706/gara-gara-rtrw,-perusahan-jepang-dan-korea-tak-jadi-berinvestasidi-riau.html, terakhir kali diakses 11 September 2016.

${ }^{11}$ Annisha meneliti tentang, Dampak Kebijakan Pelayanan Perizinan Terpadu dan Penanaman Modal Terhadap Daya Tarik Investasi Asing di Provinsi Riau Tahun 2013-2016, Jurnal JOM FISIP, Volume 4, Nomor 2, Oktober 2017, hlm. 1

${ }^{12}$ Eko N Setiawan dkk, Konflik Tata Ruang Kehutanan Dengan Tata Ruang Wilayah (Studi Kasus Penggunaan Kawasan Hutan Tidak Prosedural Untuk Perkebunan Sawit Provinsi Kalimantan Tengah), Jurnal Bhumi, Volume 3, Nomor 1, Mei 2017, hlm. 51.
} 
mentasi dan dampak desentralisasi pada sektor kehutanan di Tanjung Jabung Barat, Jambi. ${ }^{13}$ Handoyo meneliti tentang resolusi konflik di Taman Nasional Tesso Nilo Riau, Indonesia: tinjauan relasi pemangku kepentingan (conflicts resolution in Tesso Nilo National Park Riau, Indonesia: (study of stakeholder relationships). ${ }^{14}$ Irsyadi Siradjuddin meneliti tentang dampak perkebunan kelapa sawit terhadap perekonomian wilayah di Kabupaten Rokan Hulu. ${ }^{15}$

Bila ditelaah penelitian terdahulu tersebut jelas tidak ada kaitannya dengan dampak kebijakan RTRW terhadap iklim investasi bidang usaha perkebunan di Provinsi Riau. Oleh karena itu, penelitian ini merupakan sesuatu yang baru atau berbeda dengan penelitian terdahulu (novelty). Dengan demikian, penelitian ini penting dilaksanakan karena akan memberikan konstribusi yang berarti bagi ilmu pengetahuan. Adapun permasalahan yang dibahas dalam penelitian ini, yaitu Pertama, bagaimana dampak kebijakan RTRW di Riau terhadap iklim investasi bidang usaha perkebunan? Kedua, bagaimana upaya yang dilakukan di tengah ketidakpastian kebijakan RTRW terhadap investasi bidang usaha perkebunan di Provinsi Riau? Hasil yang diharapkan dari penelitian ini, yaitu menjelaskan dampak kebijakan RTRW terhadap iklim investasi bidang usaha perkebunan di Provinsi Riau. Selain itu, penelitian ini diharapkan dapat dijadikan pengembangan ilmu pengetahuan khususnya hukum bisnis yang akan bermanfaat bagi masyarakat, dunia usaha, dan/ atau industri.

\section{Metode Penelitian}

\section{Jenis penelitian}

Jenis penelitian ini adalah penelitian hukum sosiologis, pendekatannya empiris dengan cara menelaah perumusan masalah yang hendak diteliti sekaligus menjelaskan dan menganalisis dampak kebijakan RTRW terhadap iklim investasi bidang usaha perkebunan di Provinsi Riau.

\section{Lokasi penelitian}

Penelitian ini dikaitkan dengan kepastian investasi bidang usaha perkebunan di Provinsi Riau. Penentuan lokasi ini terkait fenomena mendasar yang mempengaruhi kepastian hukum investasi di Provinsi Riau, yaitu belum selesainya RTRW. Pengaruh belum selesainya RTRW berimbas terhadap investasi. Karena investasi jelas membutuh lahan/tanah, misalnya investasi perkebunan di Riau. Penyusunan tata ruang perkebunan kerap tumpang tindih dengan penguasaan lahan yang dikelola masyarakat dan perusahaan. $\mathrm{Hal}$ ini berpengaruh terhadap lambatnya proses mengurus izin dan pengukuran ulang lahan perusahaan mengakibatkan pelambatan pengembangan sektor perkebunan.

${ }^{13}$ Sudirman dkk, Mekanisme Penyusunan Kebijakan Daerah di Bidang Kehutanan Proses, Implementasi Dan Dampak Desentralisasi Pada Sektor Kehutanan di Tanjung Jabung Barat, Jambi, (Bogor: Pusat Studi Hukum dan Kebijakan Otonomi Daerah (PSHK-ODA) bekerjasama dengan Center for International Forestry Research (CIFOR), 2005), hlm. 51.

${ }^{14}$ Handoyo, Resolusi Konflik di Taman Nasional Tesso Nilo Riau, Indonesia: Tinjauan Relasi Pemangku Kepentingan (Conflicts Resolution in Tesso Nilo National Park Riau, Indonesia: Study of Stakeholder Relationships), Jurnal Analisis Kebijakan Kehutanan, Volume 12, Nomor 2, Agustus 2015, hlm. 89.

${ }^{15}$ Irsyadi Siradjuddin, Dampak Perkebunan Kelapa Sawit Terhadap Perekonomian Wilayah di Kabupaten Rokan Hulu, Jurnal Agroteknologi, Volume 5, Nomor 2, Februari 2015, hlm. 7. 


\section{Populasi dan sampel}

\section{a. Populasi}

Populasi yang terkait dengan penelitian ini adalah Kepala Dinas Perkebunan Provinsi Riau, dan Kepala Badan Penanaman Modal dan Promosi Daerah Provinsi Riau, Ketua Himpunan Tani dan Nelayan Provinsi Riau dan satu orang pelaku usaha perkebunan di Provinsi Riau.

\section{b. Sampel}

Jumlah dari populasi di atas tidak banyak masing-masing hanya berjumlah 1 (satu) orang maka secara sensus seluruhnya ditetapkan menjadi sampel.

\section{Sumber data}

a. Data primer

Merupakan data yang diperoleh dan dikumpulkan secara langsung dari sampel yang diteliti. Data tersebut digolongkan ke dalam data primer.

b. Data sekunder

Data sekunder, yaitu data yang diperoleh melalui kepustakaan yang bersifat mendukung data primer.

\section{Teknik pengumpulan data}

a. Wawancara

Wawancara dilakukan secara terstruktur, yaitu proses tanya jawab antara penulis dengan sampel mengikuti daftar pertanyaan yang telah dipersiapkan. Wawancara ini ditujukan terhadap seluruh sampel.

\section{b. Kajian kepustakaan}

Metode pengumpulan data ini dilakukan melalui peran aktif penulis untuk membaca literatur-literatur kepustakaan yang memiliki korelasi dengan permasalahan yang diteliti.

\section{Analisis data}

Data atau informasi yang diperoleh melalui teknik wawancara dikumpulkan dan disajikan dalam bentuk uraian kalimat (deskriptif), kemudian dianalisis secara kualitatif, menghubungkannya dengan peraturan perundang-undangan, konsep, teori, pandangan para ahli serta data lainnya yang relevan disajikan secara deskritif. Dari pembahasan tersebut penulis menarik kesimpulan dengan "metode induktif", yakni mengambil kesimpulan dari pernyataan yang bersifat khusus untuk ditarik kesimpulan secara umum.

\section{Pembahasan}

Dampak Kebijakan RTRW di Riau Terhadap Iklim Investasi Bidang Usaha Perkebunan

Investasi saat ini merupakan peran yang strategis untuk mendukung pembangunan yang tidak mampu dilaksanakan dan dikelola oleh negara karena keterbatasan dana. Langkah serius mendorong masuknya investasi telah dilakukan oleh pemerintah dengan mengun-dangkan Undang-Undang Nomor 25 Tahun 2007 tentang Penanaman Modal.

Khusus daerah Provinsi Riau pada tahun 2015 realisasi investasi telah memberikan konstribusi cukup besar dan menempatkan Riau pada peringkat 10 berdasarkan laporan kegiatan penanaman modal secara nasional dengan jumlah Rp 18.110.42 milyar. Pada tahun 2016 khusus untuk triwulan III realisasi investasi Penanaman Modal Dalam Negeri (PMDN)/ Penanaman Modal Asing (PMA) sejumlah Rp 5,70 triliun, terdiri dari realisasi investasi PMDN sebesar Rp 1,88 triliun dan realisasi PMA sebesar US\$282,75 juta atau setara dengan Rp 3,82 triliun, menempati peringkat 9 (sembilan) nasional untuk PMDN dan peringkat 10 (sepuluh) nasional untuk PMA. 
Kemudian capaian realisasi investasi Provinsi Riau PMDN/PMA dari Januari sampai dengan September tahun 2016 sebesar Rp 16,16 triliun, terdiri dari realisasi PMDN sebesar Rp 5,92 triliun dan realisasi PMA US\$ 745,15 juta atau senilai Rp 10,24 triliun. Pencapaian realisasi investasi PMA/PMDN ini telah melampaui target yang ditetapkan Rencana Pembangunan Jang Menengah Daerah (RPJMD) Provinsi Riau sebesar Rp 12,7 triliun dan telah mencapai $88 \%$ dari target yang ditetapkan BKPM di Provinsi Riau sebesar Rp 18,5 triliun.

Dari triwulan III tahun 2016 bidang usaha kontributor realisasi investasi PMDN/PMA masih didominasi oleh industri pengolahan crude palm oil (CPO), industri minyak kasar dari nabati (PKS), industri kertas (pulp \& papers), tanaman pangan dan perkebunan, real estate/ property dan perhotelan. Sementara berdasarkan lokasi kabupaten/kota kontributor utama dalam realisasi investasi sebagai berikut. Kota Dumai sebesar Rp 2,63 triliun, Kabupaten Siak sebesar Rp 1,07 triliun, Kabupaten Pelalawan sebesar Rp 907 milyar, diikuti Kota Pekanbaru dengan realisasi sebesar Rp 388 milyar dan Kabupaten Indragiri Hulu sebesar Rp 377 milyar.

Adapun realisasi dalam 2 (dua) tahun terakhir PMDN dan PMA menurut sektor di Provinsi Riau dari tahun 2014-2015 dapat dilihat pada tabel berikut:

\section{Realisasi Dalam 2 (Dua) Tahun Terakhir PMDN dan PMA \\ Menurut Sektor di Provinsi Riau Dari Tahun 2014-2015}

\begin{tabular}{|c|c|c|c|c|}
\hline \multirow[b]{2}{*}{ Sektor } & \multicolumn{2}{|c|}{ Tahun 2014} & \multicolumn{2}{|c|}{ Tahun 2015} \\
\hline & $\begin{array}{c}\text { PMDN } \\
\text { (Milyar Rp) }\end{array}$ & $\begin{array}{c}\text { PMA } \\
\text { (Milyar Rp) }\end{array}$ & $\begin{array}{c}\text { PMDN } \\
\text { (Milyar Rp) }\end{array}$ & $\begin{array}{c}\text { PMA } \\
\text { (Milyar Rp) }\end{array}$ \\
\hline Tanaman Pangan & - & 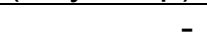 & - & \\
\hline Perkebunan & 1.217 .82 & 121.62 & 566.45 & 35.18 \\
\hline Peternakan & - & - & - & 0.008 \\
\hline Perikanan & - & - & - & - \\
\hline Kehutanan & - & - & - & - \\
\hline Pertambangan & - & 4.77 & 5.30 & 2.15 \\
\hline Industri Makanan & 652.08 & 479.79 & 1.484 .64 & 152.13 \\
\hline Konveksi & - & - & - & - \\
\hline Industri Kayu & - & 1.42 & - & - \\
\hline Industri Kertas & $2.344,77$ & 492.06 & 480.69 & 159.35 \\
\hline Industri Farmasi & - & - & - & \\
\hline Industri Kimia & 777.59 & 222.85 & 1.966 .64 & 213.32 \\
\hline Industri Mineral Logam & - & - & 305.44 & - \\
\hline Indusrti Logam Dasar & 38.70 & - & 3.03 & 0.84 \\
\hline Industri Barang Logam & 23.59 & - & 0.002 & \\
\hline Industri Lainnya & 7.95 & 4.99 & 5.06 & 0.001 \\
\hline Listrik, Air dan Gas & 2.537 .05 & 0.46 & 662.43 & 16.51 \\
\hline Bangunan/Konstruksi & - & 19.14 & 264.84 & 0.18 \\
\hline Perdagangan & - & 2.60 & 114.50 & 1.94 \\
\hline Hotel dan Restoran & 105.79 & 4.46 & 361.23 & 0.04 \\
\hline Pengangkutan & - & - & 1.015 .00 & 66.07 \\
\hline $\begin{array}{l}\text { Perumahan Kawasan } \\
\text { Industri }\end{array}$ & 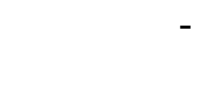 & - & 2.341 .24 & 5.67 \\
\hline Perkantoran & - & 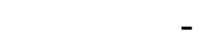 & - & - \\
\hline Jasa Lainnya & 2.21 & 15.42 & 366.54 & - \\
\hline
\end{tabular}


Dari realisasi dalam 2 (dua) tahun terakhir PMDN dan PMA menurut sektor di Provinsi Riau dari tahun 2014-2015 bidang perkebunan investasinya di Riau cukup besar pada tahun 2015 mencapai Rp 566.45 milyar (PMDN) dan
Rp 35.18 milyar (PMA). Dari realisasi tersebut telah memberikan konstribusi yang signifikan bagi pendapatan Provinsi Riau berdasarkan harga berlaku pada tahun 2012 sampai dengan 2015 dalam hitungan (jutaan rupiah) sebagai berikut.

\section{Pendapatan Provinsi Riau Berdasarkan Harga Berlaku Pada Tahun 2012 Sampai dengan 2015 Sektor Perkebunan}

\begin{tabular}{cccc}
\hline $\begin{array}{c}\mathbf{2 0 1 2} \\
\mathbf{( R p )}\end{array}$ & $\begin{array}{c}\mathbf{2 0 1 3} \\
\mathbf{( R p )}\end{array}$ & $\begin{array}{c}\mathbf{2 0 1 4} \\
\mathbf{( R p )}\end{array}$ & $\begin{array}{c}\mathbf{2 0 1 5} \\
\mathbf{( R \mathbf { p } )}\end{array}$ \\
\hline \multirow{2}{*}{65.407 .440 .90} & 70.664 .664 .20 & 82.437 .187 .00 & 85.992 .769 .40 \\
\hline
\end{tabular}

Memperhatikan data di atas maka jelaslah sektor usaha perkebunan menjadi salah satu yang dapat memberikan kontribusi bagi pendapatan dan masih terbuka peluang untuk lebih ditingkatkan. Berkaitan sektor usaha perkebunan merupakan salah investasi yang memberikan prospek bagi pendapatan maka mesti didukung dengan dasar hukum yang mendukung perizinan, memberikan kepastian hukum dan tidak tumpang tindih.

Dasar hukum yang melandasi penanaman modal secara umum, yaitu Undang-Undang Nomor 25 Tahun 2007 tentang Penanaman Modal. Undang-undang ini tidak secara khusus dikaitkan dengan bidang usaha tertentu. Dasar hukum investasi bidang usaha perkebunan dapat dikategorikan peraturan yang dibuat oleh Badan Koordinasi Penanaman Modal (BKPM) terkait dengan aspek perizinan, fasilitas, dan pengendalian investasi. Kemudian dasar hukum yang terkait langsung dengan bidang usaha perkebunan itu sendiri.

Adapun dasar hukum Badan Koordinasi Penanaman Modal (BKPM) terkait dengan aspek perizinan, fasilitas, dan pengendalian investasi sebagai berikut.
1. Peraturan Kepala Badan Koordinasi Penanaman Modal (PERKA BKPM) Nomor 14 Tahun 2015 tentang Pedoman dan Tata Cara Izin Prinsip Penanaman Modal.

2. Peraturan Kepala Badan Koordinasi Penanaman Modal (PERKA BKPM) Nomor 15 Tahun 2015 tentang Pedoman dan Tata Cara Perizinan dan Nonperizinan Penanaman Modal.

3. Peraturan Kepala Badan Koordinasi Penanaman Modal (PERKA BKPM) Nomor 16 Tahun 2016 tentang Pedoman dan Tata Cara Pelayanan Fasilitas Penanaman Modal.

4. Peraturan Kepala Badan Koordinasi Penanaman Modal (PERKA BKPM) Nomor 17 Tahun 2015 tentang Pedoman dan Tata Cara Pengendalian Pelaksanaan Penanaman Modal.

Dasar hukum yang terkait langsung dengan bidang usaha perkebunan sebagai berikut.

1. Undang Undang Nomor 39 Tahun 2014 tentang Perkebunan. 
2. Peraturan Menteri Pertanian Republik Indonesia Nomor 98/PERMENTAN/ OT.140.9/2013 tentang Pedoman Perizinan Usaha Perkebunan.

Dasar hukum yang terkait langsung dengan bidang usaha perkebunan itu sendiri sampai dengan dilaksanakannya penelitian ini tidak ada ditindaklanjuti Pemerintah Provinsi Riau dengan membuat peraturan daerah (Perda) yang secara khusus melandasi investasi bidang usaha perkebunan.

Hasil penelitian Yalid dkk pernah menyimpulkan bahwa pengaturan investasi pada Pemerintah Daerah Provinsi Riau, sejak diundangkannya Undang-Undang Nomor 25 Tahun 2007 tentang Penanaman Modal setelah ditelusuri sampai dilaksanakannya penelitian tidak ada satu perda pun yang dibuat oleh Pemerintah Daerah Provinsi Riau yang mengejawantahkan substansi undang-undang tersebut. ${ }^{16}$ Sampai saat penelitian tersebut dilakukan Pemerintah Daerah Provinsi Riau hanya membuat kebijakan dalam bentuk Surat Keputusan Gubernur yang sifatnya adalah untuk mendorong upaya terciptanya iklim investasi, dan memberikan pelayanan terhadap calon investor. Seperti Surat Keputusan Gubernur Riau No. 364/IV/2012 tentang Pembentukan Tim Koordinasi Pemantapan Iklim Investasi Provinsi Riau dan Surat Keputusan Gubernur Riau Nomor 365/IV/2012 tentang Pembentukan Tim Pelayanan Calon Investor dalam Rangka Pelaksanaan Investasi di Provinsi Riau Tahun 2012.
Sebagaimana telah disinggung pada pendahuluan, yaitu fenomena mendasar yang mempengaruhi iklim investasi di Provinsi Riau karena belum selesainya RTRW. Pengaruh belum selesainya RTRW berimbas terhadap investasi. Karena investasi jelas membutuh lahan/tanah, misalnya investasi perkebunan di Riau. Penyusunan tata ruang perkebunan kerap tumpang tindih dengan penguasaan lahan yang dikelola masyarakat dan perusahaan. Hal ini berpengaruh terhadap lambatnya proses mengurus izin dan pengukuran ulang lahan perusahaan mengakibatkan pelambatan pengembangan sektor perkebunan.

Ketidakjelasan RTRW tersebut dapat dikatakan sebagai penyebab mendasar ketidakpastian hukum bagi investasi di Riau termasuk bidang usaha perkebunan. Sebab investasi perkebunan harus menggunakan ruang atau lahan. Pendapat ini dibenarkan oleh BKPMPD Provinsi Riau dalam wawacara penulis dengan Kepala BKPMPD Provinsi Riau yang didisposisikan kepada Kepala Sub Bidang (Kasubbid) Evaluasi Pendataan dan Penanaman Modal pada BKPMPD Provinsi Riau. ${ }^{17} \mathrm{Hal}$ yang sama juga dikatakan Ketua Himpunan Tani dan Nelayan Indonesia (HTNI) Provinsi Riau. ${ }^{18}$

Dalam wawancara penulis terhadap Dinas Perkebunan Provinsi Riau menyebutkan tidak ada kendala yang dihadapi oleh investor dalam berinvestasi bidang usaha perkebunan di Provinsi Riau. Tetapi, dalam menjawab pertanyaan penulis berikutnya dengan

\footnotetext{
${ }^{16}$ Yalid dkk, Harmonisasi Hukum Investasi Nasional dengan Pengaturan Investasi di Daerah Provinsi Riau, Laporan Hasil Penelitian, 2013, hlm. 24.

${ }^{17}$ Wawancara dengan Fitriani Yulistira, S.E., M.M. selaku Kepala Sub Bidang (Kasubbid) Evaluasi Pendataan dan Penanaman Modal pada BKPMPD Provinsi Riau pada tanggal 4 Januari 2017.

${ }^{18}$ Wawancara dengan Ir. Syarifuddin Adek selaku ketua Himpunan Tani dan Nelayan Indonesia Provinsi Riau pada tanggal 20 Januari 2017.
} 
pertanyaan apakah ada kendala yang dihadapi oleh Pemerintah Provinsi Riau dalam meningkatkan investasi di bidang Perkebunan di Provinsi Riau? Selanjutnya, dijawab dengan mengatakan bahwa Pemerintah Provinsi Riau mengalami keterbatasan dana untuk memberikan bantuan dana kepada masyarakat untuk menunjang hasil produksi kebun rakyat. ${ }^{19}$ Dari wawancara ini menunjukkan lawan bicara tidak menguasai materi dan tidak memahami arah pertanyaan yang penulis ajukan.

Ketidakjelasan RTRW tersebut setidaknya menimbulkan pertanyaan, ada apa dengan persoalan RTRW Provinsi Riau itu? Bila ditelusuri Provinsi Riau pertama kali menyusun RTRW pada Tahun 1991 dan disahkan menjadi Perda Provinsi Riau pada tahun 1994 melalui Perda Nomor 10 Tahun 1994 berlaku sampai dengan tahun 2009. Dalam Perda ini, dialokasikan kebutuhan ruangnya seluas 4.341.501 Hektar ( $\mathrm{Ha})$.

Pemerintah Provinsi Riau pada tahun 2001 sudah memulai melakukan revisi terhadap Perda Nomor 10 Tahun 1994 tersebut. Selama proses revisi ini berjalan, terjadi berbagai perubahan dinamika kewilayahan, seperti pembentukan Provinsi Kepulauan Riau dan pemekaran kabupaten/kota serta berbagai aturan yang terkait perencanaan pembangunan dan pemanfaatan ruang sehingga baru selesai pada tahun 2007.

Draft revisi Perda RTRW tersebut telah diajukan ke DPRD Provinsi Riau untuk proses pembahasan menjadi Perda. DPRD membentuk Pansus dan mulai melakukan pembahasan. Namun, pada tahun yang bersamaan juga terbit Undang-Undang Nomor 26 Tahun 2007 tentang Penataan Ruang pengganti Undang-Undang Nomor 42 Tahun 1992. Berdasarkan Undang-Undang Nomor 26 Tahun 2007 terjadi perubahan yang mendasar dalam penyusunan penataan ruang. Oleh karena itu, suatu ketaatan terhadap asas maka Pemerintah Provinsi Riau secara paralel juga melakukan penyesuaian sesuai dengan substansi terhadap Undang-Undang Nomor 26 Tahun 2007 tersebut.

Tetapi, sampai dilakukannya penelitian ini Perda RTRW Provinsi Riau belum ditetapkan, karena memang masih ada penyelesaian masalah status kawasan hutan di Kementerian Kehutanan. Sesuai dinamika penggunaan ruang Surat Keputusan (SK) Nomor 173 Tahun 1986 tentang Tata Guna Hutan Kesepakatan (TGHK) tersebut tidak lagi sesuai dengan dinamika pengunaan ruang. Wilayah seluruh Riau merupakan kawasan hutan apabila merujuk pada SK Kementerian Kehutanan tersebut, bahkan kantor Gubernur Riau masuk kawasan hutan. Selain itu, seluruh kab/kota di Provinsi Riau masa berlaku Perda RTRW-nya habis masa berlakunya. Keadaaan ini membuat kekosongan hukum, dalam artian legal formal aturan yang mengatur mulai dari perencanaan, pemanfaatan dan pengendalian pemanfaatan ruang tidak ada.

Tentunya, Pemerintah Daerah Provinsi Riau termasuk daerah kabupaten/kota di Riau tidak berani mengambil risiko hukum menerbitkan izin baru untuk investasi perkebunan. Adapun risikonya pidana dan denda sebagaimana diatur dalam Undang-Undang Nomor 26 Tahun 2007 tentang Penataan Ruang Pasal 69 Ayat (1), dengan ketentuan bahwa setiap orang yang tidak menaati rencana tata ruang yang telah ditetapkan yang mengakibatkan perubahan fungsi ruang, dipidana dengan pidana penjara paling lama 3 (tiga) tahun dan denda paling banyak Rp 500.000.000,00 (lima ratus juta rupiah). Oleh karena itu, perizinan investasi bidang usaha perkebunan menjadi terhenti. 
Tidak adanya izin baru untuk investasi bidang perkebunan dikemudian hari tentu dapat menimbul persoalan. Hal ini karena membuka dan menggarap tanah untuk usaha perkebunan di Riau tetap saja berjalan, meskipun tidak diberi izin. Keadaan ini dikatakan seorang pelaku usaha perkebunan yang menjadi sampel dalam penelitian ini. ${ }^{20}$ Maridup mengatakan "jika dikemudian hari RTRW Provinsi Riau berhasil diselesaikan, ternyata tidak sesuai dengan penggunaan lahan perkebunan yang sudah terlanjur dikelola sebelumnya, justru menimbulkan penolakan". ${ }^{21}$ Selain itu, lahan yang telah dikelola sebelumnya tidak bisa memberikan konstribusi pendapatan khususnya bagi Pemerintah, karena tidak ada dasar hukum mengutip pajak dari usaha perkebunan tersebut, inilah dampak dari kekosongan kebijakan RTRW tersebut.

Keadaan inilah yang mempengaruhi iklim investasi di Provinsi Riau sejalan dengan pendapat yang menyatakan stabilitas dan prediktibilitas kebijakan merupakan komponen yang mempengaruhi investasi menurut Mahmul Siregar, ${ }^{22}$ kepastian hukum berusaha menurut Sugeng Praptono memberikan kepastian ke depan yang jelas (predictability ${ }^{23}$ dan menurut Leonard J. Theberde. ${ }^{24}$

Dengan demikian, dapat dikatakan belum selesainya RTRW berpengaruh terhadap iklim investasi yang sangat mendasar dalam investasi di Riau. Meskipun kegiatan penanaman modal bersifat sangat kompleks, karena terkait dengan bidang-bidang hukum lain sebagaimana telah disinggung baik berdimensi nasional maupun internasional. Untuk memastikan kepastian hukum kegiatan penanaman modal bersifat sangat kompleks tersebut tidak bisa dijawab dengan analisis ini melainkan memerlukan penelitian lanjutan.

\section{Upaya yang Dilakukan di tengah Ketidak- pastian Kebijakan RTRW Terhadap Investasi Bidang Usaha Perkebunan di Provinsi Riau}

Sebagaimana telah dibahas bahwa realisasi investasi di Provinsi Riau dalam 2 (dua) tahun terakhir PMDN dan PMA menurut sektor di Provinsi Riau dari tahun 2014-2015 bidang perkebunan investasinya di Riau cukup besar pada tahun 2015 mencapai Rp 566.45 milyar (PMDN) dan Rp 35.18 milyar (PMA). Dari realisasi tersebut telah memberikan konstribusi yang signifikan bagi pendapatan Provinsi Riau. Jumlah tersebut masih dapat meningkat lagi sepanjang tidak ada kendala bagi masuknya investor. Tetapi, telah diketahui bahwa hambatan investasi bidang usaha perkebunan di Provinsi Riau justru sangat mendasar, yaitu adanya ketidakjelasan RTRW.

Pemerintah Daerah Provinsi Riau termasuk daerah kabupaten/kota di Riau jelas tidak berani mengambil risiko hukum menerbitkan izin baru untuk investasi perkebunan sebagaimana dibatasi dengan ketentuan Undang-Undang Nomor 26 Tahun

\footnotetext{
${ }^{19}$ Wawancara dengan Enni Edina, SP selaku Kepala Seksi (Kasi) Pembinaan Perkebunan Besar pada Dinas Perkebunan Provinsi Riau pada tanggal 22 Desember 2016.

${ }^{20}$ Wawancara dengan Maridup Siahaan pelaku usaha perkebunan jeruk nipis yang membuka usaha di Provinsi Riau pada tanggal 21 Januari 2017.

${ }^{21}$ /bid.

${ }^{22}$ Mahmul Siregar, Kepastian Hukum...Op.Cit., hlm. 6.

${ }^{23}$ Sugeng Praptono, Beberapa Problematika Investasi di Era Otonomi Daerah, Jurnal Yustisia, Nomor 71, Mei-Agustus 2007, hlm. 85.

${ }^{24}$ Leonard J. Theberde dalam Sugeng Praptono, Beberapa Problematika...Op.Cit., hlm. 86.
} 
2007 tentang Penataan Ruang. Meskipun demikian, Pemerintah Daerah Provinsi Riau harus melakukan upaya, katakanlah upaya di tengah ketidakkepastian kebijakan RTRW yang melandasi investasi bidang usaha perkebunan.

Menurut Kepala BKPMPD Provinsi Riau dalam wawancara dengan penulis yang secara teknis jawabannya didisposisikan kepada Kepala Sub Bidang (Kasubbid) Evaluasi Pendataan dan Penanaman Modal pada BKPMPD Provinsi Riau, mengemukakan bahwa "upaya yang dilakukan dengan selalu berkoordinasi dengan Pemerintah Pusat agar masalah RTRW tersebut dapat terselesaikan dengan secepatnya". ${ }^{25}$ Dari jawaban tersebut, memberikan keterangan bahwa investasi bidang usaha perkebunan tetap berpegang dengan RTRW. Artinya, sepanjang tidak ada kepastian RTRW Pemerintah Provinsi Riau tidak berani memberikan izin bagi investor bidang usaha perkebunan untuk menggunakan lahan.

Investasi bidang usaha perkebunan yang sudah berjalan sampai saat ini hanyalah investasi berdasarkan ketentuan RTRW yang lama. Tetapi, tidak akan diberikan izin bagi investor baru untuk mendapatkan lahan yang baru pula. Meskipun menjanjikan konstribusi yang signifikan bagi pendapatan Provinsi Riau.

Dari wacana terakhir persoalan RTRW Provinsi Riau akan segera selesai. Menurut Gubernur Riau investasi Riau pada 2017 tidak lagi dihambat oleh kawasan hutan karena draf RTRW akan disahkan oleh Kementerian Lingkungan Hidup dan Kehutanan. Perjuangan mendapatkan kepastian RTRW tersebut telah melalui proses panjang dan sangat menguras energi. Berdasarkan dokumen ekspose RTRW Provinsi Riau Desember 2015 menunjukkan proses yang telah dilakukan Pemerintah Daerah Provinsi Riau dalam rangka percepatan penyelesaian RTRW Provinsi Riau:

1. Setelah 5 Desember 2012, Pemerintah Provinsi Riau telah menyampaikan permintaan percepatan perubahan kawasan hutan Riau (tertulis dan secara lisan disampaikan dalam forum resmi) ke Presiden, Dewan Perwakilan Rakyat (DPR), Badan Koordinasi Penataan Ruang Nasional (BKPRN), Kemendagri, Menko Perekonomian, Unit Kerja Presiden Bidang Pengawasan dan Pengendalian Pembangunan (UKP4) dan instansi pusat terkait lainnya, secara tertulis sebanyak 8 kali.

2. Melakukan konfirmasi ke Kementerian Lingkungan Hidup dan Kehutanan terkait tindak lanjut permasalahan Kawasan Hutan di Riau, dan Kementerian Lingkungan Hidup dan Kehutanan menjanjikan akan adanya pertemuan antara Kementerian, Kejagung, Komisi Pemberantasan Korupsi (KPK) dan Pemerintah Provinsi Riau.

3. Permohonan penyelesaian kawasan hutan ke Ombudsman.

4. Fasilitasi percepatan penyelesaian RTRW Provinsi Riau oleh Kementerian Koordinator Bidang Perekonomian sebanyak 4 kali.

5. Rapat/pertemuan dengan Kementerian Lingkungan Hidup dan Kehutanan

\footnotetext{
${ }^{25}$ Wawancara dengan selaku Fitriani Yulistira, S.E., M.M Kepala Sub Bidang (Kasubbid) Evaluasi Pendataan dan Penanaman Modal pada BKPMPD Provinsi Riau pada tanggal 4 Januari 2017.
} 
secara intens sejak 2012, terakhir pada tanggal 19 Agustus 2015.

Upaya-upaya tersebut sampai saat ini memang belum membuahkan hasil. Hasilnya masih berupa wacana, yaitu diperkirakan bulan Februari 2017 RTRW Riau akan segera disahkan. Gubernur Riau itu, menyebutkan masalah RTRW ini sangat berdampak kepada realisasi investasi. Sejumlah investor asing dan dalam negeri menunda investasi senilai Rp 22 triliun, karena dibatasi kawasan hutan. Meski investasi terhambat, Gubernur Riau mengatakan pembangunan infrastruktur nasional, seperti pembangunan jalan tol TransSumatera dan jalur kereta api sudah bisa dilanjutkan. Selama ini, pemerintah beserta DPRD setempat tidak bisa mengeluarkan regulasi karena masih berada di kawasan hutan.

\section{Kesimpulan}

1. Dampak kebijakan RTRW di Riau terhadap iklim investasi bidang usaha perkebunan saat ini sangat berpengaruh terhadap masuknya investor baru disebabkan belum selesainya RTRW yang melandasi pengunaan ruang/lahan. Dapat dikatakan belum selesainya RTRW mempengaruhi iklim investasi di Riau. Pemerintah Provinsi Riau pada tahun 2001 sudah memulai melakukan revisi terhadap Perda Nomor 10 Tahun 1994 tersebut. Tetapi, sampai dilakukannya penelitian ini Perda RTRW Provinsi Riau belum ditetapkan, karena memang masih ada penyelesaian masalah status kawasan hutan di Kementerian Kehutanan. Tentunya, Pemerintah Daerah Provinsi Riau termasuk daerah kabupaten/ kota di Riau tidak berani mengambil risiko hukum menerbitkan izin baru untuk investasi perkebunan.
2. Upaya yang dilakukan di tengah ketidakkepastian kebijakan RTRW terhadap investasi bidang usaha perkebunan di Provinsi Riau dapat dikatakan hanya menunggu pengesahan Perda RTRW Provinsi Riau. Meskipun bidang usaha perkebunan memberikan konstribusi yang signifikan bagi pendapatan Provinsi Riau. Upaya yang dilakukan adalah dengan selalu berkoordinasi dengan Pemerintah Pusat agar masalah RTRW tersebut dapat terselesaikan dengan secepatnya, diperkirakan bulan Februari 2017 RTRW Riau akan segera disahkan.

\section{Saran}

1. Sementara menunggu pengesahan Perda RTRW Provinsi Riau maka untuk meningkat tetap meningkatkan investasi sebaiknya Pemerintah Provinsi Riau membenahi faktor-faktor lain untuk meningkatkan pendapatan dari bidang usaha perkebunan

2. Apabila pengesahan RTRW Provinsi telah terwujud maka sebaiknya Pemerintah Provinsi Riau segera melakukan publikasi dan memberikan pemahaman kepada semua pihak yang terkait dan berkepentingan sehingga akan memaksimalkan pelaksanaannya ke depan.

\section{Referensi}

Annisha. Dampak Kebijakan Pelayanan Perizinan Terpadu dan Penanaman Modal Terhadap Daya Tarik Investasi Asing di Provinsi Riau Tahun 2013-2016. Jurnal JOM FISIP. Volume 4. Nomor 2. Oktober 2017.

Dellisa A. Ridgway dan Mariya A. Thalib, Globalization and Development : Free Trade, Foreign Aid, Investment and The Rule of Law, California Western 
International Law Journal, Volume 33, Spring 2003.

Duhita Driyah Suprapti. Politik Hukum Investasi di Era Otonomi Daerah. Jurnal Pandecta. Volume 4. Nomor 2. Tahun 2010.

Eko N Setiawan dkk. Konflik Tata Ruang Kehutanan Dengan Tata Ruang Wilayah (Studi Kasus Penggunaan Kawasan Hutan Tidak Prosedural Untuk Perkebunan Sawit Provinsi Kalimantan Tengah). Jurnal Bhumi. Volume 3. Nomor 1. Mei 2017.

Erman Rajagukguk. 2005. Hukum Investasi di Indonesia. Jakarta: Fakultas Hukum Universitas Indonesia.

Hans-Rimbert Hemmer, et.all. 2002. Negara Berkembang dalam Proses Globalisasi Untung atau Buntung? Jakarta: Konrad Adenauer Stifftung.

Handoyo. Resolusi Konflik di Taman Nasional Tesso Nilo Riau, Indonesia: Tinjauan Relasi Pemangku Kepentingan (Conflicts Resolution in Tesso Nilo National Park Riau, Indonesia: Study of Stakeholder Relationships. Jurnal
Analisis Kebijakan Kehutanan. Volume 12. Nomor 2. Agustus 2015.

Irsyadi Siradjuddin. Dampak Perkebunan Kelapa Sawit Terhadap Perekonomian Wilayah di Kabupaten Rokan Hulu. Jurnal Agroteknologi. Volume 5. Nomor 2. Februari 2015.

Mahmul Siregar. 2010. Kepastian Hukum dalam Transaksi Bisnis Internasional dan Implikasinya Terhadap Kegiatan Investasi di Indonesia. Program Studi IImu Sekolah Pascasarjana Universitas Sumatera Utara.

Sudirman dkk. 2005. Mekanisme Penyusunan Kebijakan Daerah di Bidang Kehutanan Proses, Implementasi dan Dampak Desentralisasi Pada Sektor Kehutanan di Tanjung Jabung Barat, Jambi. Bogor: Pusat Studi Hukum dan Kebijakan Otonomi Daerah (PSHK-ODA) bekerjasama dengan Center for International Forestry Research (CIFOR).

Sugeng Praptono. Beberapa Problematika Investasi di Era Otonomi Daerah, Jurnal Yustisia. Nomor 71. Mei-Agustus 2007. 